\begin{tabular}{|c|c|c|}
\hline & Journal Homepage: -www.journalijar.com & $\begin{array}{l}\text { INTERNATIONAL JOURNAL OF } \\
\text { ADVANCED RESEARCH (JIAR) }\end{array}$ \\
\hline ISSN NO. 2320-5407 & $\begin{array}{l}\text { Article DOI:10.21474/IJAR01/7810 } \\
\text { DOI URL: http://dx.doi.org/10.21474/IJAR01/7810 }\end{array}$ & \\
\hline
\end{tabular}

RESEARCH ARTICLE

\title{
THE SIGNIFICANCE OF SATISFACTION IN LOYALTY AND WORD OF MOUTH OF INDONESIA PRIVATE HIGHER EDUCATION CUSTOMER.
}

Nani Fitriani ${ }^{1}$ and Sri Wahyuni ${ }^{2}$.

1. Faculty of Management, Asian Banking Finance and Informatics Institute (ABFII) Perbanas Jakarta, Indonesia.

2. Graduate School, Asian Banking Finance and Informatics Institute (ABFII) Perbanas Jakarta, Indonesia.

\section{Manuscript Info}

Manuscript History

Received: 5 August 2018

Final Accepted: 7 September 2018

Published: October 2018

Keywords: Customer Satisfaction, Customer Loyalty, Word of Mouth, Higher Education

\section{Abstract}

Higher education institutions, especially private universities or private colleges, which are now regarded as service providers in education industry must find creative ways to survive. There are many ways they can perform to maintain the loyalty of their customers and to spread up positive information about them. One of those can be done by increasing customer satisfaction. This study aims at analyzing how customer satisfaction influence customer loyalty and word of mouth in private higher education in Indonesia. This study takes primary data. The data gathered using questionnaire, distributed to 200 undergraduate students of private colleges in Jakarta. The data data processed using statistical calculations Structural Equation Modeling (SEM) with the help of computer program Analysis of Moment Structure (AMOS). The result of construction confirmatory test shows that the coefficient of direct influence between customer satisfaction and customer loyalty has positive and significant value, that is 2.667. Moreover, customer satisfaction has positive significant influence on word of mouth, with the coefficient of 3.025. Thus, increasing student satisfaction will impact on their loyalty and word of mouth activities. Therefore, the effort to increase student satisfaction must be improved in order to increase loyalty and word of mouth.

Copy Right, IJAR, 2018,. All rights reserved.

\section{Introduction:-}

\section{Background}

The increasingly intense competition among universities has triggered universities, particularly private universities, to increase customer satisfaction to increase student loyalty. In addition, increased customer satisfaction is expected to contribute to student activities in distributing information about the campus.

Higher education institutions are now regarded as education service provider industry to survive (Li: 2013). Moreover, private universities or colleges must find and use certain means that can increase the number of students and maintain student loyalty to compete with other universities, including government universities. Furthermore, private universities can perform many ways in order to maintain the loyalty of service users as well as to spread up positive things about them, such as increasing the satisfaction of service users. 
In addition to customer satisfaction and loyalty factors, often the existence of a product is also known by the public through word of mouth. Research conducted by Kazemi et al (2013) shows that 90\% of people buy a product based on information from family and friends. This means that marketing through WOM is much more effective than those of other media. In WOM, people tell about their experience of a product or service that they use to the people they know.

Based on that explanation, I am interested to explore the influence of indicators that reflect and define all research variables as well as analyze the role of customer satisfaction in customer loyalty and word of mouth of the private higher education in Jakarta.

\section{Customer Satisfaction}

Kotler (2003) explains satisfaction as a feeling of pleasure or disappointment that is felt by someone after he compares the perception of the performance or the outcome of a product in the hope. From the explanation, it can be underlined that there are two major elements compared in satisfaction, which are the performance or outcome of a product and customer expectations. Conversely, customer expectations are also influenced by several factors, such as experiences, opinions of others, as well as the company's promises. Smart company managers will always pay attention to customer satisfaction. It needs to be done to establish a good relationship between the company and the customer. Good relationships that exist between the company and the customer will make the company more competitive.

Zeithaml and Bitner (2002) suggested several factors that affect customer satisfaction, namely:

1. Product or service features; Directly customer satisfaction is influenced by product or service features.

2. Emotional customers; Refers to a state of mind, feeling, or customer mood that can affect a customer's response to a product or service.

3. Attribution of service success or failure: refers to the cause of an event affecting the customer's perception of satisfaction.

4. Perceptions of fairness and fairness: refers to customer perceptions that compare treatment to itself with the treatment of other customers.

5. Other users: information obtained by customers from service users around them may affect the perception of satisfaction of a service, for example information that he obtained from family members, friends, or neighbors.

\section{Customer Loyalty}

Loyalty is a commitment to buy or subscribe to a product or service in the future Kotler and Keller (2007). This commitment is not influenced by the market situation that allows the change of behavior of market participants. Loyalty is divided into two, namely brand loyalty and store loyalty. Brand loyalty is a consistent use attitude over a brand. Brand loyalty is characterized by consistent purchases of specific brands. Store loyalty (store loyalty) is a consistent attitude toward the selection of a store.

According to Kotler and Keller (2009) loyalty can be measured from several indicators, namely:

1. Repeat purchase, refers to loyalty to purchases of certain products.

2. Retention ie resilience to negative issues about the company.

3. Referral is referencing the existence of a company.

\section{Word of Mouth}

In the world of marketing, word of mouth communication (WOM) is known as the most effective way to introduce products to the public. In addition, this type of communication also does not require a high cost. The effectiveness of WOM as a marketing medium is inseparable from the culture of the world community who likes to share or tell the experience.

WOM is defined as informal communication among the community that contains the experience or satisfaction / dissatisfaction of a person for the product or service he uses. This information is delivered verbally (word of mouth) from one person to another so that it becomes an infinitely long chain.

Experts and marketing actors divide WOM into two, namely buzz marketing and viral marketing (Kotler \& Keller, 2012). Buzz marketing brings happiness, creates publicity, and usually produces other products related to products to market. In the buzz of marketing, marketers usually create conditions for products or services to be sold into many people's conversations. Conto buzz marketing is a rampant community of Harry Potter lovers who used 
various Harry Potter knick-knacks before the Harry Potter movie was launched. Viral marketing is often called word of mouse. Marketing of this type is designed like a virus that can spread quickly. Today, the internet and social media have a huge share in viral marketing. Millions of information about a product will be spread out in seconds as marketers or social media users hit the "share" or "share" button.

The effectiveness of marketing through WOM is also expressed by Hart et al. (1990). However, these experts emphasize that the level of customer satisfaction greatly affects WOM. According to their research, one dissatisfied customer will share his experience with 11 prospects, while a satisfied customer will share his experience with only 6 customers.

\section{Relationship among Variables}

The development of hypotheses in this study is based on the results of previous studies. The relationship between the variables in this study as investigated by Li (2013), Kazemi et.al (2013), Ha \& Hyunjoo (2013), Taylor et.al. (2004), Tores et.al (2008), Ham (2003) can be described as follows.

The development of hypotheses in this study is based on the results of the previous studies. The relationship between the variables in this study as investigated by Li (2013), Kazemi et.al (2013), Ha \& Hyunjoo (2013), Taylor et.al. (2004), Tores et.al (2008), Ham (2003) can be described as follows.

\section{Pic 1:-Research Model}

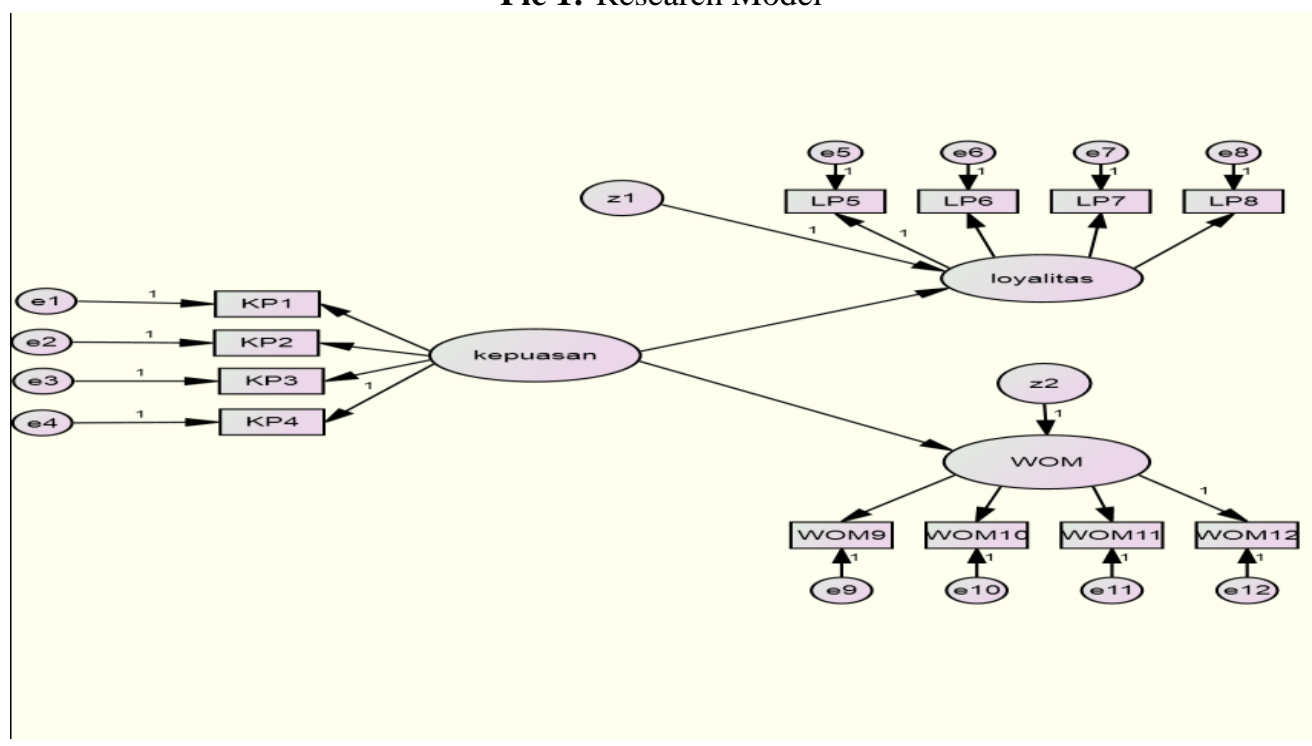

The Influence of Observed Variables on Customer Satisfaction.

The indicators of customer satisfaction, which are the observed variables in this study include campus services, employee reliability, campus facilities, and customer satisfaction. Selection of these indicators is based on research conducted by Zeithaml and Bitner (2002).

H1: There is a significant positive influence between campus services, employee reliability, campus facilities, and customer emotions on customer satisfaction.

\section{The Influence of Observed Variables on Customer Loyalty}

Indicators, which are treated as observed variables on customer loyalty variables include repurchase, resistance to negative issues, and recommend products, as expressed by Kotler and Keller (2006: 57).

H2: There are significant positive effects between repeat purchase, resistance to negative issues, and activities recommending customer loyalty.

\section{The Influence of Observed Variables on Word of Mouth}

The observed variables in the word of mouth variables are telling about the benefits of campus, telling a happy feeling, telling good things about the campus to others, and sharing feelings of pride in others. These indicators are based on paada (Kotler \& Keller, 2012: 571).

H3: There is a significant positive influence between telling the benefits of campus, telling happy feelings, telling good things about campus to others, and telling people feelings of pride in others. 


\section{The Influence of Customer Satisfaction on Customer Loyalty}

Customer satisfaction is a sign that the company has met the customer's expectation of the company's service to him. Cordozo in Chang Li (2003) argues that customer satisfaction will encourage the behavior of repurchasing products in the same company. In other words, customers who are satisfied with the services received from a company will have a loyal tendency to the company.

Research conducted by Kasim and Abdullah (2010) states that satisfaction affects customer trust and customer confidence affect customer loyalty. Another study that mentions the influence of customer satisfaction on customer loyalty is research conducted by Luarn \& Lin (2003). Based on these findings, the fourth research hypothesis (H4) in this study is as follows.

H4: There is an effect of customer satisfaction on customer loyalty.

\section{The Influence of Customer Satisfaction on WOM}

Customer satisfaction is a reflection of the fulfillment of customer expectations on the quality of service they received. Satisfied customers will share their experiences with people he or she knows. This informal sharing process will lead to the recommendation process.

Previous studies have shown that customer satisfaction affects WOM. Ranaweera and Prabhu (2003) revealed that customer satisfaction and trust are two important factors that can create WOM. Another study that revealed the influence of customer clinging to WOM was a study conducted by Kazemiet et al (2013) on Melat Bank customers in Kermanshah. Based on the results of previous studies, the fifth hypothesis in this study is as follows.

H5: There is an effect of customer satisfaction on WOM.

\section{Method:-}

This research takes primary data. The data gathered using questionnaire, distributed to 200 undergraduate students of private university in Jakarta. The data data processed using statistical calculations Structural Equation Modeling (SEM) with the help of computer program Analysis of Moment Structure (AMOS)

\section{Discussion:-}

Testing the Unidimensionality of each Construct with Confirmatory Factor Analysis (CFA)

\section{Confirmatory Test for Customer Satisfaction Construct}

The result of Confirmatory Test of Customer Satisfaction construct by using SEM is as follows.

Table 1:-Confirmatory Test Result of Customer Satisfaction Exogenous ConstructsRegression Weights: (Group number 1 - Default model)

\begin{tabular}{|l|l|l|r|r|r|r|l|}
\hline & & & Estimate & S.E. & C.R. & P & Label \\
\hline KP4 & $<---$ & satisfaction & 1.000 & & & & \\
\hline KP1 & $<---$ & satisfaction & 1.222 & .092 & 13.294 & $* * *$ & par_1 \\
\hline KP3 & $<---$ & satisfaction & 1.314 & .110 & 11.910 & $* * *$ & par_2 \\
\hline KP2 & $<---$ & satisfaction & 1.208 & .091 & 13.261 & $* * *$ & par_3 \\
\hline
\end{tabular}

Standardized Regression Weights: (Group number 1 - Default model)

\begin{tabular}{|c|l|l|l|}
\hline & & & Estimate \\
\hline KP4 & $<--$ & satisfaction & .807 \\
\hline KP1 & $<--$ & satisfaction & .913 \\
\hline KP3 & $<--$ & satisfaction & .830 \\
\hline KP2 & $<---$ & satisfaction & .918 \\
\hline
\end{tabular}

Source: Primary Data (2016)

\section{Confirmatory Test for Customer Loyalty}

Below is the result of Confirmatory Test of Customer Loyalty construct using SEM. 
Table2:-Confirmatory Test Result of Customer Loyalty Exogenous Constructs Regression Weights: (Group number 1 - Default model)

\begin{tabular}{|c|c|c|c|c|c|c|c|}
\hline & & & Estimate & S.E. & C.R. & $P$ & Label \\
\hline LP1 & $<--$ & loyalty & 1.000 & & & & \\
\hline LP2 & $<--$ & loyalty & .740 & .172 & 4.291 & $* * *$ & par_1 \\
\hline LP3 & $<---$ & loyalty & .723 & .132 & 5.474 & $* * *$ & par_2 \\
\hline LP4 & $<--$ & loyalty & 1.393 & .263 & 5.289 & $* * *$ & par_3 \\
\hline
\end{tabular}

Standardized Regression Weights: (Group number 1 - Default model)

\begin{tabular}{|c|c|c|c|}
\hline & & & Estimate \\
\hline LP1 & $<--$ & loyalty & .543 \\
\hline LP2 & $<--$ & loyalty & .393 \\
\hline LP3 & $<--$ & loyalty & .523 \\
\hline LP4 & $<---$ & loyalty & 1.007 \\
\hline
\end{tabular}

Source: Primary Data (2016)

\section{Confirmatory Test for Word of Mouth}

Below is the result of Confirmatory Test of Word of Mouth construct using SEM.

Table3:-Confirmatory Test Result of Word of Mouth Exogenous ConstructsRegression Weights: (Group number 1 Default model)

\begin{tabular}{|l|l|l|r|r|r|r|r|}
\hline & & & Estimate & S.E. & C.R. & P & Label \\
\hline WOM4 & $<---$ & WOM & 1.000 & & & & \\
\hline WOM3 & $<---$ & WOM & 1.045 & .075 & 13.852 & $* * *$ & par_1 \\
\hline WOM2 & $<---$ & WOM & 1.037 & .060 & 17.430 & $* * *$ & par_2 \\
\hline WOM1 & $<---$ & WOM & 1.106 & .069 & 15.925 & $* * *$ & par_3 \\
\hline
\end{tabular}

Standardized Regression Weights: (Group number 1 - Default model)

\begin{tabular}{|l|l|l|r|}
\hline & & & Estimate \\
\hline WOM4 & $<---$ & WOM & .876 \\
\hline WOM3 & $<---$ & WOM & .841 \\
\hline WOM2 & $<---$ & WOM & .938 \\
\hline WOM1 & $<---$ & WOM & .906 \\
\hline
\end{tabular}

Source: Primary Data (2016)

\section{Confirmatory Test for Customer Satisfaction and Customer Loyalty Construct}

Confirmatory test results of customer satisfaction with customer loyalty constructs can be seen in the following figure and table.

Table 4:-Confirmatory Test Results of Customer Satisfactio and Customer Loyalty ConstructsRegression Weights: (Group number 1 - Default model)

\begin{tabular}{|l|l|l|r|r|r|r|r|}
\hline & & & Estimate & S.E. & C.R. & P Label \\
\hline loyalty & $<---$ & satisfaction & .868 & .142 & 6.113 & $* * *$ & par_7 \\
\hline KP4 & $<---$ & satisfaction & 1.000 & & & & \\
\hline KP3 & $<---$ & satisfaction & 1.298 & .107 & 12.117 & $* * *$ & par_1 \\
\hline KP2 & $<---$ & satisfaction & 1.190 & .088 & 13.581 & $* * *$ & par_2 \\
\hline KP1 & $<---$ & satisfaction & 1.206 & .089 & 13.596 & $* * *$ & par_3 \\
\hline LP5 & $<---$ & satisfaction & 1.000 & & & & \\
\hline LP6 & $<---$ & satisfaction & .780 & .169 & 4.622 & $* * *$ & par_4 \\
\hline LP7 & $<---$ & satisfaction & .714 & .130 & 5.473 & $* * *$ & par_5 \\
\hline LP8 & $<---$ & satisfaction & 1.236 & .171 & 7.227 & $* * *$ & par_6 \\
\hline
\end{tabular}


Standardized Regression Weights: (Group number 1 - Default model)

\begin{tabular}{|l|l|l|r|}
\hline & & & Estimate \\
\hline loyalty & $<---$ & satisfaction & .770 \\
\hline KP4 & $<---$ & satisfaction & .816 \\
\hline KP3 & $<---$ & satisfaction & .830 \\
\hline KP2 & $<---$ & satisfaction & .915 \\
\hline KP1 & $<---$ & satisfaction & .911 \\
\hline LP5 & $<---$ & loyalty & .573 \\
\hline LP6 & $<---$ & loyalty & .437 \\
\hline LP7 & $<---$ & loyalty & .545 \\
\hline LP8 & $<---$ & loyalty & .944 \\
\hline
\end{tabular}

From the table above can be concluded that the indicators that greatly affect the relationship between customer satisfaction with customer loyalty is KP2 (0.915) on customer satisfaction and LP8 (0.944) on customer loyalty.

\section{Confirmatory Test for Customer Satisfaction and Word of Mouth Construct}

Confirmatory test results of customer satisfaction construct with Word of Mouth can be seen in the following figure and table.

Table 5:-Confirmatory Test Results of Customer Satisfaction and Word of Mouth Constructs Regression Weights: (Group number 1 - Default model)

\begin{tabular}{|l|l|l|r|r|r|r|r|}
\hline & & & Estimate & S.E. & C.R. & P & Label \\
\hline WOM & $<---$ & satisfaction & .944 & .098 & 9.588 & $* * *$ & par_1 \\
\hline KP4 & $<---$ & satisfaction & 1.000 & & & & \\
\hline KP3 & $<---$ & satisfaction & 1.296 & .105 & 12.391 & $* * *$ & par_2 \\
\hline KP2 & $<---$ & satisfaction & 1.173 & .086 & 13,632 & $* * *$ & par_3 \\
\hline KP1 & $<---$ & satisfaction & 1.191 & .087 & 13.672 & $* * *$ & par_4 \\
\hline WOM8 & $<---$ & WOM & 1.000 & & & & \\
\hline WOM7 & $<---$ & WOM & 1.039 & .075 & 13.891 & $* * *$ & par_5 \\
\hline WOM6 & $<---$ & WOM & 1.045 & .058 & 17.889 & $* * *$ & par_6 \\
\hline WOM5 & $<---$ & WOM & 1.091 & .069 & 15.806 & $* * *$ & par_7 \\
\hline
\end{tabular}

Source: Primary Data (2016)

Standardized Regression Weights: (Group number 1 - Default model)

\begin{tabular}{|l|l|l|r|}
\hline & & & Estimate \\
\hline WOM & $<--$ & satisfaction & .767 \\
\hline KP4 & $<--$ & satisfaction & .824 \\
\hline KP3 & $<--$ & satisfaction & .835 \\
\hline KP2 & $<---$ & satisfaction & .910 \\
\hline KP1 & $<---$ & satisfaction & .908 \\
\hline WOM8 & $<---$ & WOM & .878 \\
\hline WOM7 & $<---$ & WOM & .838 \\
\hline WOM6 & $<---$ & WOM & .946 \\
\hline WOM5 & $<---$ & WOM & .895 \\
\hline
\end{tabular}

Source: Primary Data (2016)

From the table above can be concluded that the indicators that greatly affect the relationship between customer satisfaction with WOM is KP2 (0.910) on customer satisfaction and WOM6 (0.946) in word of mouth.

The structural equation model in this study as a whole has met the fit criteria. Although the value of RMSEA of 0.110 and probability of 0,000 , the minimum chi-square value for existing data of 462.112 is good. In addition, the GFI (0.766), AGFI (0.703), NFI (0.892), and TLI (0.864) values were marginal. The value of CMIN / DF in this study of 2.801 indicates fit model. 
After conducting confirmatory tests on all variables, it is known that almost all indicators have met the convergent validity with loading factor $>0.5$. Thus, the data in the full model diagram is valid and has a good convergence value. CGA results can be seen in the following table.

Tabel 6:-Confirmatory Test Results of all ConstructsRegression Weights: (Group number 1 - Default model)

\begin{tabular}{|l|l|l|r|r|r|r|r|}
\hline & & & Estimate & S.E. & C.R. & P & Label \\
\hline WOM & $<---$ & satisfaction & 3.025 & .860 & 3.516 & $* * *$ & par_4 \\
\hline loyalty & $<---$ & satisfaction & 2.677 & .793 & 3.375 & $* * *$ & par_5 \\
\hline KP4 & $<---$ & satisfaction & 1.000 & & & & \\
\hline KP3 & $<---$ & satisfaction & 1.263 & .110 & 11.453 & $* * *$ & par_13 \\
\hline KP2 & $<---$ & satisfaction & 1.146 & .089 & 12.936 & $* * *$ & par_14 \\
\hline KP1 & $<---$ & satisfaction & 1.152 & .090 & 12.734 & $* * *$ & par_15 \\
\hline LP5 & $<---$ & loyalty & 1.000 & & & & \\
\hline LP6 & $<---$ & loyalty & .841 & .173 & 4.873 & $* * *$ & par_16 \\
\hline LP7 & $<---$ & loyalty & .709 & .130 & 5.456 & $* * *$ & par_17 \\
\hline LP8 & $<---$ & loyalty & 1.207 & .157 & 7.676 & $* * *$ & par_18 \\
\hline WOM12 & $<---$ & WOM & 1.000 & & & & \\
\hline WOM11 & $<---$ & WOM & 1.043 & .075 & 13.980 & $* * *$ & par_19 \\
\hline WOM10 & $<---$ & WOM & 1.038 & .058 & 17.773 & $* * *$ & par_20 \\
\hline WOM9 & $<---$ & WOM & 1.102 & .068 & 16.091 & $* * *$ & par_21 \\
\hline
\end{tabular}

Source: Primary Data (2016)

Standardized Regression Weights: (Group number 1 - Default model)

\begin{tabular}{|l|l|l|r|}
\hline & & Estimate \\
\hline WOM & $<--$ & satisfaction & 2.410 \\
\hline loyalty & $<---$ & satisfaction & 2.346 \\
\hline
\end{tabular}

Source: Primary Data (2016)

\section{Hypothesis Testing}

The influence of campus services, employee reliability, campus facilities, and customer emotions on customer satisfaction.

From the confirmatory test results of Customer Satisfaction construct, it can be seen that the convergent validity of all indicators is greater than 0.5 . This indicates that the data obtained is valid. From the table above, KP2 indicator has the greatest influence to customer satisfaction, with value equal to 0.918 .

The influence of repeat purchase, resistance to negative issues, and activities recommending customer loyalty. Based on the confirmation test results of the construct of Customer Loyalty, it can be seen that the convergent validity of all indicators is greater than 0.5, except LP2 of 0.393 (marginal). From the table above, the LP4 indicator has the greatest influence on customer loyalty, with a value of 1.007 .

The influence between telling college excellences, telling a happy feeling, telling good things about campus to others, and telling a feeling of pride to others on WOM

From the result of Confirmatory test of Word of Mouth construct, it can be seen that the convergent validity of all indicators is greater than 0.5. This indicates that the data obtained is valid. From the table above, the WOM2 indicator has the greatest influence on Word of Mouth, with a value of 0.938 .

\section{The Influence of Customer Satisfaction Variables on Customer Loyalty}

The value of direct influence of customer satisfaction variable on customer loyalty is 2.364 with critical ratio value (CR) equal to 3.375 and probability $(\mathrm{P})$ equal to 0,000 . From the table above we can see that customer satisfaction variables affect the customer loyalty variable because the value of $C R> \pm 1.96$ and the value of $P<0.005$. The magnitude of direct coefficient effect between customer satisfaction variable to customer loyalty is 2.677 . This coefficient shows that there is a positive effect of customer satisfaction variable on customer loyalty. From the results of this hypothesis test can be said that the increasing customer satisfaction has an impact on increasing customer loyalty. 


\section{The Influence of Customer Satisfaction on Word of Mouth}

The value of direct influence of customer satisfaction variable on word of mouth is 2.410 with critical ratio value (CR) equal to 3.516 and probability $(\mathrm{P})$ equal to 0,000 . These figures show that customer satisfaction variables affect the word of mouth variables because the value of $\mathrm{CR}> \pm 1.96$ and the value of $\mathrm{P}<0.005$. The direct coefficient influence of customer satisfaction variable on customer loyalty is 3.025. This coefficient shows that there is a positive effect of customer satisfaction variable on word of mouth. Therefore, it can be said that the increasing customer satisfaction has impact on the increase of word of mouth.

\section{Conclusions and Recommendations:-}

\section{Conclusions:-}

The conclusion of this research is customer satisfaction influence customer loyalty and word of mouth. The result of construction confirmatory test shows that the coefficient of direct influence between customer satisfaction and word of mouth has positive and significant value (2.677). Customer satisfaction also has positive significant influence on customer loyalty, with the coefficient of 3.025. Thus, increasing student satisfaction will impact on increasing their loyalty and word of mouth activities. Therefore, the effort to increase student satisfaction must be improved in order to increase loyalty and word of mouth.

\section{Recommendation:-}

Based on the findings in this study, there are several recommendations to be addressed to private campuses and subsequent research related to marketing at private universities.

The results of this study indicate that there are some things that must be improved by the campus management such as increasing the level of customer satisfaction. Thing that must be considered in improving the quality of service is the improvement of the building and the modernization of learning facilities. Data also proves that customer satisfaction plays an important role in the formation of customer loyalty and word of mouth activities conducted by the customer. Loyal customers, in addition to re-purchasing products offered by the campus (such as continuing to higher education), will also have immunity to negative issues about the Perbanas Institute. In addition, they will also recommend the campus to people they meet.

For next studies related to marketing in private higher education, it is advisable to bring up other factors that may directly influence the formation of customer loyalty and word of mouth, such as pricing strategies and marketing communication strategies.

\section{References:-}

1. Chang Li, S. (2013). Exploring the Relationship among Service Quality, Customer Loyalty, and Word of Mouth for Privare Higher Education in Taiwan". Asia Pacific Management Review. 18 (4): 375-389.

2. Ha \& Hyunjoo. Role of Website Design Quality in Satisfaction and Word of Mouth Generation. (2012). Journal of Service Management. 23 (1): 79-96.

3. Ham, Carrie Leugenia. (2003) Service Quality, Customer Satisfaction, and Customer Behavioral Intention in Higher Education.Southern University. Doctoral Dissertation.

4. Harrison - Walker, L. Jean. (2001). The Measurement of Word of Mouth Communication and an Investigation of Service Quality and Customer Commitment as Potential Anticedents. Journal of Service Research: JSR. 4(1): 60-75.

5. Hart, Christopher, James L. Heskett, and W. Earl Sasser Jr. (1990). "The Profitable Art of Service Recovery." Harvard Business Review, Vol. 68 (July/August): 148- 156.

6. Kasim, Norizan; Abdullah, Mor Asiah.(2010)The Effect of Perceived Service Quality

7. dimensions on Customer Satisfaction, Trust, and Loyalty in e-commerce Setting: A Cross Cultural Analysis. Asia Pacific Journal of Marketing and Logistics. 22.3 : $351-371$.

8. Kazemi, A., Paemami, V., Abbaszadeh, A., Pourzamani, J. (2013). "Impact of Brand Identity on Customer Loyalty and Word of Mouth Communications, Considering Mediating Role of Customer Satisfaction and Brand Commitment. (Case Study: Customers of Mellat Bank in Kermansah)". International Journal of Academic Research in Economics and Management Sciences. 2(4): 1-14.

9. Kotler, Philip. (2003).Marketing Management, $11^{\text {th }}$ Edition. New Jersey: Prentice HallInc.

10. Kotler, Philip dan Kevin Lane Keller, (2007), Marketing Management $13^{\text {th }}$ Edition, Pearson Education Inc. 
11. Kotler, Phillip dan Kevin Lane Keller (2009), Marketing Management. New Jersey: Pearson Education.

12. Kotler, Philip dan Kevin Lane Keller. (2012). Marketing Management $14^{\text {th }}$ Edition. New Jersey: Pearson Education.

13. Taylor, Steven A.; Hunter, Gary L; Linberd, Deborah L. (2007). Understanding customer-based brand equity in financial services. (2007)The Journal of Marketing 21.4: 241 - 252.

14. Taylor, Steven; Celuch, Kelvin; Goodwin, Stephen. (2004). The Importance of Brand Equity to Customer Loyalty (in heavy equipment manufacture). The Journal of Product and Brand Management. 13. 4/5: 217 - 227

15. Tores - Moraga, Eduardo; Aturoz, Vasquez - Parraga; Jorge Zamora - Gonzales (2008). Customer Satisfaction and Loyalty: Start with the product, communicate with the brand. The Journal of Consumer Marketing 25.5: $302-313$.

16. Zeithaml, V. A. and Bitner, M. Jo.(2002). Service Marketing. New York: McGraw Hill. 